\title{
SỬ DỤNG SÓNG CAO TÀN TRONG ĐIỀU TRI GIÃN TĨNH MẠCH NÔNG CHI DƯớI
}

Nguyễn Văn Việt Thành* Nguyễn Hoài Nam*

Tù khoá: suy tĩnh mạch (vein insufficiency), giãn tĩnh mạch (varicose vein), xơ hóa tĩnh mạch bằng sóng cao tần (radio frequency ablation - RFA)

\section{MỞ ĐẦU}

Suy tĩnh mạch mạn tính chi dưới là bệnh lý khá thường gặp, chiếm khoảng 40,5\% người trên 50 tuổi, nữ giới nhiều gấp 4,25 lần so với nam giới [Error! Reference source not found.]. Tổn thương có thể gặp ở tĩnh mạch nông, tĩnh xuyên, tĩnh mạch sâu hoặc ở cả 3 hệ tĩnh mạch của chi dưới [0]. Riêng về bệnh lý tĩnh mạch nông, một cách tổng quát, ta có thể phân thành 3 nhóm sau: nhóm suy tĩnh mạch mạn tính, nhóm giãn tĩnh mạch, nhóm viêm tắc tĩnh mạch. Điều trị suy tĩnh mạch chi dưới nói chung và suy - giãn tĩnh mạch nông nói riêng được phân làm 2 mảng chính: nội khoa và ngoại khoa. Điều trị ngoại khoa chủ yếu vẫn là phẫu thuật. Từ các thập niên 80 - 90 của thế kỉ 20, các phương pháp can thiệp nội mạch trong điều trị suy - giãn tĩnh mạch nông chi dưới lần lượt được thực hiện và đã mở ra một bước tiến mới trong điều trị bệnh lý suy tĩnh mạch chi dưới $[0,0,0,0,16]$.

\section{II. ĐỊNH NGHĨA}

Suy tĩnh mạch là tình trạng tổn thương của hệ thống van ở tĩnh mạch chi dưới dẫn đến sự trào ngược của dòng máu hướng tâm. Tổn thương có thể gặp ở cả 3 hệ tĩnh mạch nông, sâu và xuyên $[0,0,0,0]$.

Giãn tĩnh mạch được định nghĩa như là một đoạn tĩnh mạch giãn to, dài ra, có thể thấy nằm ngoằn ngoèo ngay dưới $\mathrm{da}[0,0,0,0]$. Giãn tĩnh mạch được phân thành nguyên phát và thứ phát. Giãn tĩnh mạch nguyên phát là tình trạng giãn nở của một đoạn tĩnh mạch dẫn đến hậu quả mất đi chức năng cản máu chảy ngược về của các van tĩnh mạch. Ngược lại, giãn tĩnh mạch thú phát là hậu quả của sự suy van gây nên tình trạng ứ trệ và giãn nở của một đoạn tĩnh mạch [0].

\section{LICH SỬ}

Năm 1891, D'Arsonval lần đầu tiên mô tả liệu pháp ứng dụng sóng cao tần trong y học. Ban đầu, liệu pháp ứng dụng sóng cao tần chỉ được triển khai trong lãnh vực thần kinh vào khoảng thập niên 90 . Sau đó, phương pháp này dần phát triển hơn cùng với sự phát triển của y học và khoa học kỹ thuật. Từ đó, người ta bắt đầu nghiên cứu, ứng dụng nó nhiều hơn trong y học. Năm 1999, liệu pháp dùng sóng cao tần trong y học (hay còn gọi là RFA) được chính thức giới thiệu lần đầu tiên trên thế giới tại một hội thảo ở New zealand. Bước đầu, nó chỉ được dùng như một liệu pháp phụ hỗ trợ cho phẫu thuật. Về sau, liệu pháp này đã được sử dụng rộng rãi hơn và từng bước trở thành một liệu pháp điều trị quan trọng nhu: cắt, đốt các tế bào ung thư, tiêu hủy hoặc hàn kín các mạch máu, dây thần kinh bị hư hại trong cơ thể...

Phương pháp can thiệp nội tĩnh mạch bằng nhiệt cao tần trong điều trị suy - giãn tĩnh mạch nông chi dưới được công bố vào năm 1998 tại châu Âu. Nguyên lý của phương pháp này là tác dụng nhiệt trực tiếp lên thành tĩnh mạch để làm teo và xơ hoá tĩnh mạch giãn. Đến năm 1999, FDA cấp phép công nhận RFA là một kỹ thuật điều trị trong bệnh lý suy tĩnh mạch và được sử dụng tại Hoa Kỳ. Cho đến nay, kỹ thuật này đã

\footnotetext{
*Bộ môn Ngoại lồng ngực tim mạch - ĐH Y Dược TP. HCM Ngườ chịu trách nhiệm khoa học: PGS.TS Nguyễn Hoài Nam Ngày nhận bài: 01/02/2019 - Ngày Cho Phép Đăng: 23/03/2020 Phản Biện Khoa học: PGS.TS. Đặng Ngoc Hùng
} GS.TS. Lê Ngoc Thành 
được sử dụng tại nhiều nước trên thế giới, kể cả các nước trong khu vực Đông Nam Á như Thái Lan, Philippin, Singapore. Nhiều nghiên cứu tại nhiều trung tâm thực hiện cho thấy đây là một phương pháp có hiệu quả cao, an toàn và thẩm mỹ, so với điều trị bằng phẫu thuật kinh điển. Cuối 2009 đầu năm 2010, bệnh viện Đại Học Y Dược Thành phố Hồ Chí Minh bước đầu triển khai và ứng dụng thành công kỹ thuật sử dụng sóng cao tần trong điều trị suy tĩnh mạch mạn tính chi dưới. $[0,0,14,16]$.

IV. CHẨN ĐOÁN $[0,0,13,15]$

\section{Triệu chứng cơ năng:}

- Bệnh nhân thường không có triệu chứng

\section{Triệu chứng thực thể:}

\section{Các dạng giãn tĩnh mạch nông chi dưới}

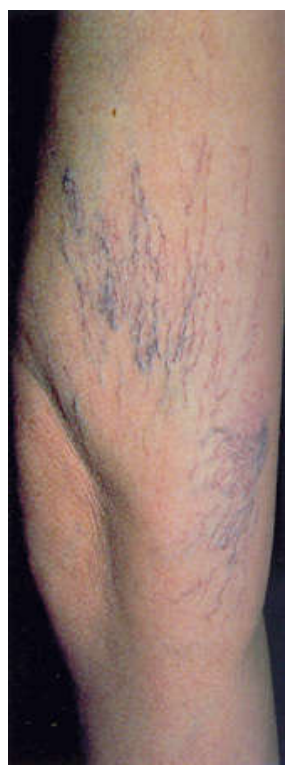

- Giãn các tĩnh mach trong da

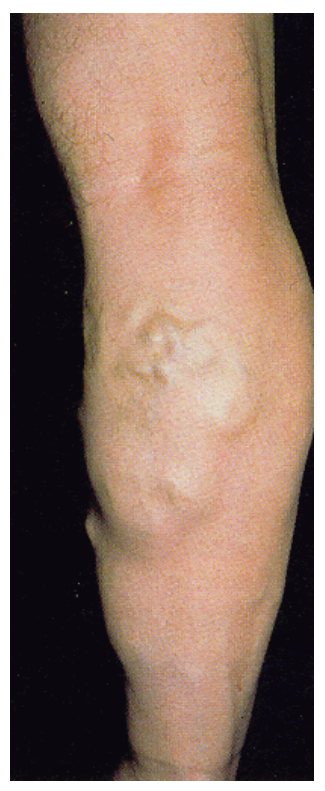

- Giãn tĩnh mach dạng luới hay triệu chứng nhẹ trong trường hợp giãn tĩnh mạch trong da, giãn tĩnh mạch dạng lưới hay giãn nhẹ thân tĩnh mạch. Vấn đề than phiền chủ yếu là thẫm mỹ.

- Cảm giác đau, nặng chân nhất là về chiều, tê, nóng rát, ngứa.

- Phù chân nhẹ, thường là ở vùng cổ chân, nặng dần về chiều, sau một ngày làm việc, giảm khi nằm kê chân cao, tiếp xúc với lạnh hoặc mang vớ thun băng ép.

Một số triệu chứng khác có thể liên quan đến suy tĩnh mạch mạn tính như vọp bẻ vào ban đêm, cảm giác mỏi chân, chân không "ngơi nghi’”.

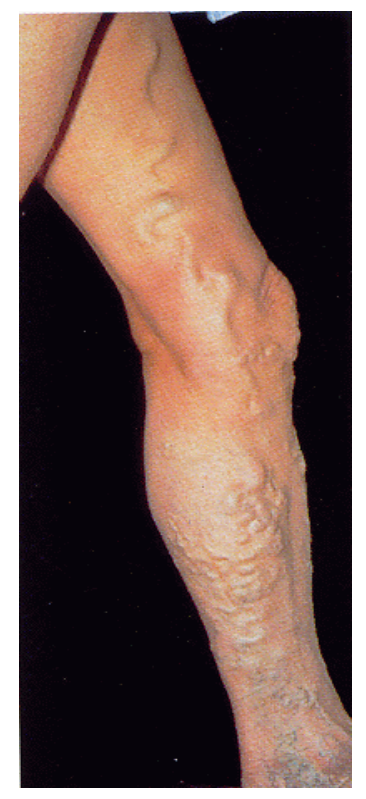

- Giãn thân tĩnh mach hiển lón

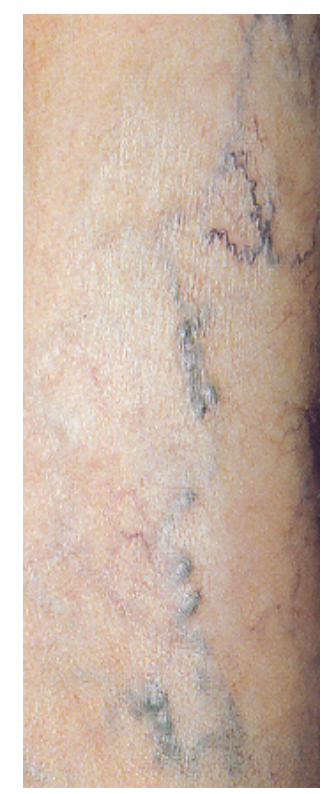

- Giãn thân tĩnh mạch hiển bé

Hình 1: Các dạng giãn tĩnh mạch nông chi dưới

\section{Khám lâm sàng}

Tư thế bệnh nhân khi khám: đứng trên bục cao và nằm ngửa, người khám chú ý quan sát:

- Sự hiện diện của các nhánh tĩnh mạch giãn và nhận diện về mặt giải phẫu học. Các tĩnh mạch này thuộc đường đi của tĩnh mạch hiển lớn, hiển bé, các nhánh phụ, các nhánh thông nối, các nhánh bàng hệ...

- Dấu hiệu phù chân, một bên hay hai bên, đối xứng hay không. Vị trì phù ở bàn chân, cẳng 
chân hoặc ở đùi. Trong trường hợp phù kín đáo, năng của các van tĩnh mạch nông:

có thể dùng thước dây để đo và so sánh hai chân.

- Các thay đổi ở da do biến dưỡng như rối loạn sắc tố da, viêm da hạ bì, chàm hóa, teo da, loét...

Trong thăm khám, nhiều nghiệm pháp chuyên biệt được sử dụng giúp ích cho chẩn đoán và điều trị. Việc thực hiện và lý giải kết quả của các nghiệm pháp này rõ ràng không đơn giản và mất nhiều thời gian. Người khám có thể áp dụng một số nghiệm pháp sau để phát hiện sự mất chức
Nghiệm pháp gõ sóng (nghiệm pháp Schwartz):

Nghiệm pháp này nhằm xác định tình trạng suy van tĩnh mạch hiển. Bệnh nhân đứng, người khám dùng đầu ngón tay của 2 bàn tay đặt trên đoạn tĩnh mạch hiển giãn. Khoảng cách 2 bàn tay khoảng $10 \mathrm{~cm}$. Ngón trên gõ vào đoạn tĩnh mạch giãn, ngón dưới sẽ cảm nhận được xung động của dòng phụt ngược từ trên truyền tới. Khi đó, nghiệm pháp $(+)$, nghĩa là có suy van tĩnh mạch hiển.

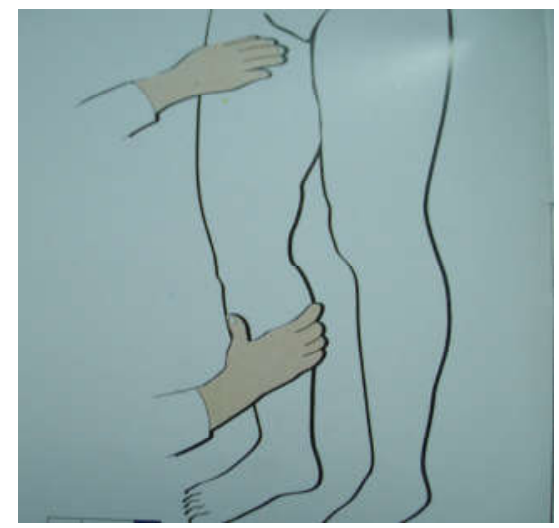

\section{Hình 2: Nghiệm pháp gõ sóng (nghiệm pháp Schwartz)}

\section{Nghiệm pháp ho:}

Nghiệm pháp này nhằm xác định suy van tĩnh mạch hiển - đùi. Bệnh nhân ở tư thế đứng, người khám để ngón tay ngay tại điểm tĩnh mạch hiển lớn đổ vào tĩnh mạch đùi, có thể sử dụng máy siêu âm Doppler bỏ túi, đặt đầu dò tại điểm trên. Cho bệnh nhân ho gây tăng áp lực đột ngột trong bụng, gây chèn ép tĩnh mạch chủ dưới tạo ra dòng phụt ngược. Nghiệm pháp $(+)$ khi người khám cảm nhận được dòng phụt ngược dội vào tay hay nghe được âm thanh phụt ngược trên máy siêu âm Doppler bỏ túi.

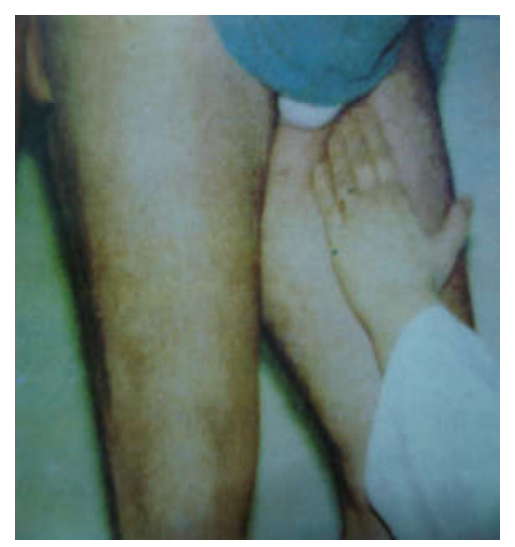

Hình 3: Nghiệm pháp ho 


\section{Nghiệm pháp Trendelenburg:}

Nghiệm pháp này nhằm xác định suy van tĩnh mạch hiển và suy van tĩnh mạch xuyên. Bệnh nhân nằm ngửa, nâng cao chân để máu trong tĩnh mạch hiển lớn dồn hết vào tĩnh mạch sâu, đặt garô (chỉ ép tĩnh mạch) ở sát nếp bẹn. Sau đó, cho bệnh nhân đứng dậy quan sát. Khi chưa mở garô, nếu các quai tĩnh mạch giãn xuất hiện lại trong vài giây (dưới 30 giây) từ dưới lên thì chứng tỏ có suy van tĩnh mạch xuyên. Khi mở garô, nếu van tĩnh mạch hiển lớn bị suy thì các quai tĩnh mạch giãn xuất hiện trở lại từ trên xuống trong vòng 30 giây (nghiệm pháp dương tính). Nghiệm pháp âm tính khi tĩnh mạch giãn trở lại từ dưới lên với thời gian trên 30 giây.

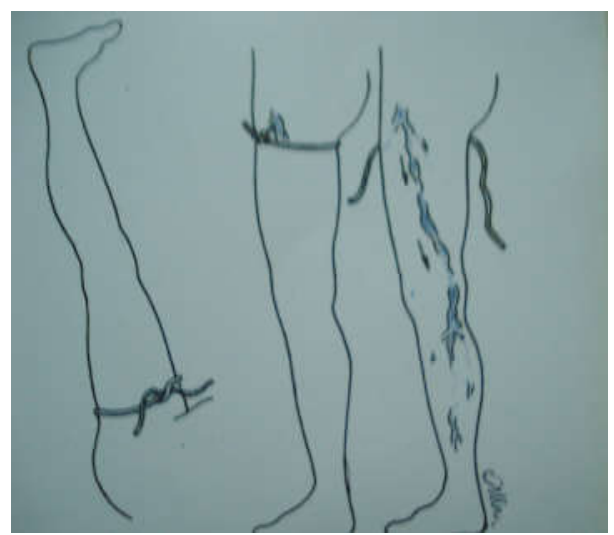

\section{Hình 4: Nghiệm pháp Trendelenburg}

\section{Cận lâm sàng:}

Siêu âm Doppler màu: cho chúng ta các thông tin liên quan đến chức năng van của tĩnh mạch hiển, các nhánh xuyên, tĩnh mạch sâu. Đây là phương pháp chẩn đoán hình ảnh không xâm lấn, kết quả chính xác và có thể thực hiện nhiều lần.

Đo dung tích tĩnh mạch khi vận động (hay test kích thích bơm của khối cơ cẳng chân): đánh giá chức năng bơm của khối cơ và khớp cũng như chức năng của các van hệ sâu và nông.

Chụp tĩnh mạch giãn cản quang: đánh giá mối quan hệ giữa các tĩnh mạch giãn với hệ thống sâu và các tĩnh mạch hiển. Ngoài ra, còn cho thấy vị trí, chức năng van của các nhánh xuyên, nơi đổ vào tĩnh mạch sâu của tĩnh mạch hiển lớn và bé.
Phân loại:

\section{Bảng phân loại CEAP}

CEAP là tập hợp các chữ đầu của các yếu tố trong phân loại viết theo tiếng Anh: Clinical severity (độ nặng lâm sàng), Etiology (căn nguyên), Anatomy (giải phẫu), Pathophysiology (sinh lý bệnh).

\section{Phân loại theo lâm sàng}

$\mathrm{C} 0$ :không thấy hoặc sờ được có tĩnh mạch giãn

$\mathrm{C} 1$ : có giãn mao mạch hay giãn tĩnh mạch dạng lưới, có kích thước nhỏ hơn $3 \mathrm{~mm}$

C2: giãn thân tĩnh mạch, có kích thước lớn hơn $3 \mathrm{~mm}$

C3: phù

C4: loạn dưỡng da (thay đổi sắc tố da, viêm da, xơ mỡ da...)

C5: loạn dưỡng da và có sẹo loét 
C6: loạn dưỡng và loét da

Kết hợp thêm:

A: không triệu chứng

S: triệu chứng

\section{Phân loại theo căn nguyên}

Ec: bẩm sinh

Ep: nguyên phát

Es: thứ phát (hậu huyết khối)

En: không xác định được nguyên nhân

\section{Phân loại theo giải phẫu}

As: tĩnh mạch nông

Ad: tĩnh mạch sâu

Ap: tĩnh mạch xuyên

An: không xác định được

\section{Phân loại theo sinh lý bệnh}

Pr: trào ngược

Po: tắc nghẽn

$\mathrm{Pr}+\mathrm{o}$ : trào ngược và tắc nghẽn

Pn: không xác định được

Lợi điểm của bảng phân loại CEAP là có thể xác định được nguyên nhân, vị trí giải phẫu, sinh bệnh học, từ đó có thể tiên lượng và đánh giá được kết quả điều trị. Tuy nhiên, bất lợi là khá phức tạp, và không xác định được mức độ trầm trọng của bệnh.

\section{Bảng phân loại Porter}

- Giai đoạn 1: Không triệu chứng

- Giai đoạn 2: Suy tĩnh mạch nhẹ, phù ở mắt cá chân, giãn tĩnh mạch

- Giai đoạn 3: Suy tĩnh mạch trung bình, viêm da, phù, xơ mõ̃ da, giãn tĩnh mạch

- Giai đoạn 4: Suy tĩnh mạch nặng, phù rõ, tổn thương loạn dưỡng da, loét

Lợi điểm của bảng phân loại này là đơn giản, dễ đánh giá, xếp loại, thấy được mức độ nặng của bệnh. Tuy nhiên, bảng này không giúp phân loại chi tiết về lâm sàng, giải phẫu, sinh bệnh học giống như phân loại CEAP.

\section{TIẾN TRIỂN VÀ BIẾN CHÚNG}

Tiến triển [13, 15]:

Nếu không được điều trị kịp thời, bệnh sẽ tiến triển nặng dần. Theo diễn tiến lâm sàng, bệnh được chia thành 2 giai đoạn:

- Thời kỳ còn bù: Bệnh nhân có cảm giác tức, nặng và mỏi ở chi dưới khi đứng lâu, có thể xuất hiện phù nề nhẹ ở cẳng - bàn chân vào cuối ngày làm việc, nghỉ ngơi thì hết phù nề. Các tĩnh mạch nông ở chân giãn chưa nhiều, lúc giãn lúc không. Khi gần mất bù, các triệu chứng của thời kỳ còn bù phát triển nặng lên. Khi đi lại, xuất hiện cảm giác đau tức nhiều ở cẳng chân. Triệu chứng phù thường xuyên hơn, thường vẫn còn ngay cả khi bệnh nhân nghỉ ngơi. Các quai tĩnh mạch nông giãn to thường xuyên.

- Thời kỳ mất bù: thường xuyên có cảm giác tê chân, ngứa da vùng tổn thương, đau nhiều ở chân khi đi bộ. Triệu chứng phù nề không mất đi khi nghỉ ngơi. Các tổn thương da do loạn dưỡng xuất như: viêm da, xơ cứng da, loét...

Biến chứng $[0,0,0]$ :

- Huyết khối: huyết khối hình thành ở tĩnh mạch bị giãn do tình trạng ứ trệ. Huyết khối có thể trôi vào hệ sâu và xa hơn nữa có thể gây biến chứng thuyên tắc phổi đe doạ tính mạng người bệnh.

- Xuất huyết do vỡ tĩnh mạch giãn thường là do chấn thương, có thể chấn thương nhẹ, vào vùng tĩnh mạch giãn, hiếm khi vỡ tự nhiên. Chảy máu có thể nguy hiểm nếu vỡ các thân tĩnh mạch nông chính.

- Xo mõ da: là quá trình xơ hóa dần dần da và lớp mỡ dưới da do suy tĩnh mạch. Bệnh nguyên của xơ mõ̃ da chưa rõ. Nhiều cơ chế đã được đề cập như tăng áp lực tĩnh mạch, sự bắt giữ các bạch cầu gây phóng thích các men tiêu protein, sự lắng đọng fibrin quanh mao 
mạch...Quá trình xơ mỡ da thường được xác định tương đối rõ và khu trú ở vùng thấp của cẳng chân và vùng mắt cá. $\mathrm{Da}$ trở nên chai cứng lại và bóng. Lớp mỡ dưới da trở nên dày và cứng. Lớp hạ bì chai lại và dính với các lớp bên dưới. Sang thương này khi ấn thấy mềm. Có thể thấy giãn tĩnh mạch tại vùng bị xơ hóa và da ở phía trên tĩnh mạch có thể không bị tăng sắc tố ngay cả khi những vùng da xung quanh sẫm màu. Trong giai đoạn cấp, da có thể tương đối bình thường và bệnh nhân có thể than đau, nóng, rát bỏng ở vùng thấp của cẳng chân.

- Teo da trắng: là một thay đổi điển hình ở bệnh nhân suy tĩnh mạch. Thường gặp ở phụ nữ hơn, nằm ở mắt cá trong và mu bàn chân. Tên được gọi như vây là do màu sắc và hình thái của da. Sang thương đặc trưng bởi những vùng giới hạn rõ ở thượng bì, tăng sắc tố và nhợt nhạt do thiếu những mao mạch làm mất màu hồng bình thường trên da. Khi không có mao mạch nuôi dưỡng, da bị thiếu máu cục bộ. Do đó mô da rất yếu và dễ bị chấn thương. Đôi khi, sang thương được bao quanh bởi những vùng tăng sắc tố và rải rác có hình ảnh sao mạch (mao mạch giãn và kéo dài). Loét kết hợp khá thường gặp (1/3 trường hợp) tại vùng teo da trắng. Loét thường nhiều ổ, kích thước nhỏ, rất đau và chậm lành. Teo da trắng cũng có thể là một sẹo loét chân do tĩnh mạch đã lành.
- Chàm: Viêm da chàm hóa thường phát triển trong quá trình suy tĩnh mạch. Những bất thường về mao mạch do ứ máu tĩnh mạch có thể kèm theo những sang thương chàm hóa có giới hạn rõ hoặc lan tỏa. Hiện tượng này, có thể do tăng áp lực tĩnh mạch, bắt giữ và hoạt hóa bạch cầu gây ra viêm. Bề mặt da thường khô và láng. Sang thương này rất ngứa và thường kèm theo viêm thần kinh da thứ phát.

- Loét chân: được xem là biến chứng da cuối cùng và nặng nề nhất của suy tĩnh mạch. Loét chân do tĩnh mạch thường khu trú ở vùng thấp của cẳng chân đến phía trên mắt cá trong, rất hiếm khi xảy ra ở mu bàn chân hoặc ngón chân. Khởi đầu loét có thể âm thầm hoặc đột ngột sau chấn thương, xuất huyết do vỡ tĩnh mạch giãn, nhiễm trùng da.

\section{VI. ĐIỀU TRI BẦNG PHƯƠNG PHÁP SỬ DỤNG SÓNG CAO TÀ̀N}

Co chế tác dụng: Đây là phương pháp hủy mô bằng nhiệt, gây ra bởi sự ma sát của các ion trong mô dưới tác động của dòng điện xoay chiều có tần số nằm trong khoảng sóng âm thanh (200 $1.200 \mathrm{MHz}$ ). Dòng điện được truyền từ máy vào mô cơ thể qua một điện cực dạng kim (needle electrode), dòng sóng radio được truyền vào đầu kim và sinh nhiệt. Nhiệt do ma sát làm khô mô xung quanh dẫn đến làm mất nước trong tế bào và hoại tử đông phần mô cần hủy [18].

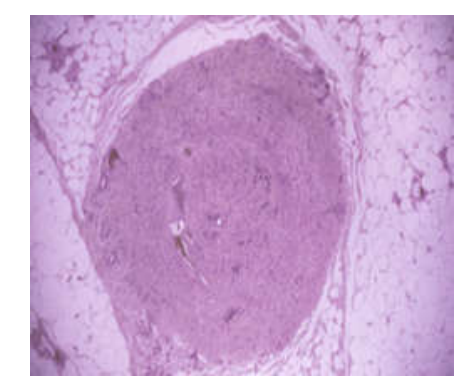

B: Biến đổi tĩnh mạch trên giải phẫu bệnh

A: Mức độ lan rộng của tác dụng nhiệt

Hình 5: Cơ chế tác dụng của sóng cao tần 


\section{Chỉ định và chống chỉ định điều trị laser} nội tĩnh mạch

\section{Chỉ định}

Những bệnh nhân giãn tĩnh mạch nông chi dưới thỏa các yêu cầu sau [14, 17, 20, 21]:

- Giãn tĩnh mạch hiển và có dòng trào ngược trên siêu âm doppler

- $5 \mathrm{~mm} \leq$ đường kính thân tĩnh mạch hiển $\leq 12 \mathrm{~mm}$

\section{Chống chỉ định}

Những bệnh nhân giãn tĩnh mạch nông nhưng lại kèm theo các vấn đề sau $[0,14,17$, 20, 21]:

- Huyết khối tĩnh mạch sâu

- Huyết khối tĩnh mạch hiển đoạn gần quai

- Dị dạng động - tĩnh mạch

- Giãn nhánh tĩnh mạch nông nhưng tĩnh mạch hiển không suy - giãn

- Tĩnh mạch hiển giãn ngoằn ngoèo không thể luồn guide wire

- Bệnh nhân có thai và đang cho con bú

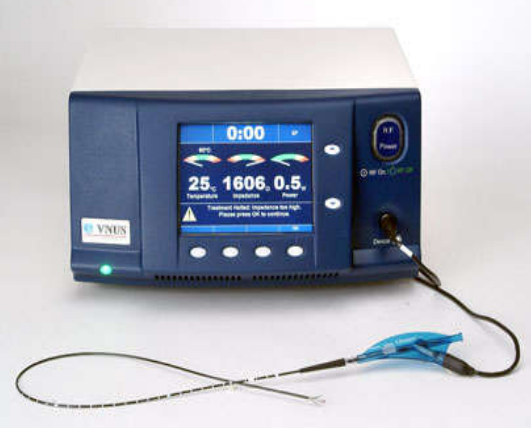

\section{Chuẩn bị bệnh nhân trước thủ thuật}

Những bệnh nhân có chỉ định điều trị can thiệp nội tĩnh mạch đều được chuẩn bị như một cuộc mổ, bao gồm:

- Một số các xét nghiệm tiền phẫu

- Giải thích rõ cho bệnh nhân và người nhà, cho kí cam kết

- Làm vệ sinh chân cần can thiệp

- Vẽ bản đồ tĩnh mạch dưới siêu âm bằng mực không tan trong nước, xác định các yếu tố sau: vị trí và đường kính quai tĩnh mạch hiển, đánh dấu vị trí cách quai $2 \mathrm{~cm}$, đường kính thân tĩnh mạch, dòng trào ngược, vị trí đâm kim

- Kháng sinh trước mổ: trước lúc thực hiện thủ thuật 30 phút

- Lập đường truyền tĩnh mạch

\section{Kỹ thuật thực hiện}

\section{Dụng cụ}

- Máy siêu âm mạch máu

- Máy đốt nhiệt bằng sóng cao tần

Bộ dụng cụ can thiệp mạch máu.

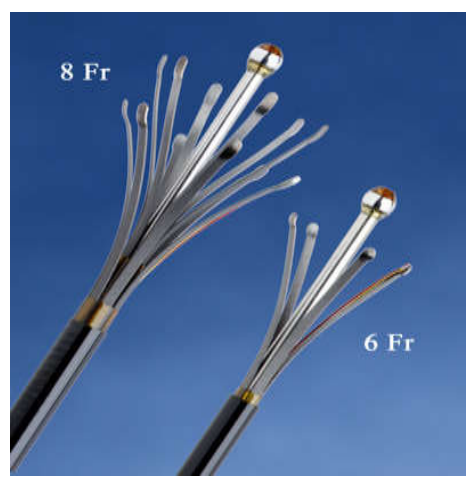

\section{Hình 6: Máy đốt nhiệt bằng sóng cao tần}

Tư thế bệnh nhân [14, 17, 20, 21]

- Đối với can thiệp tĩnh mạch hiển lớn: Bệnh nhân được cho nằm ngửa, chân được điều trị hơi giạng và xoay ngoài, gối hơi gấp để bộc lộ vùng mặt trong đùi
- Đối với can thiệp tĩnh mạch hiển bé: Bệnh nhân được cho nằm sấp, hai chân duỗi thẳng, bộc lộ mặt sau cẳng chân và vùng khoeo.

\section{Vô cảm}

- Tê tủy sống

- Tê tại chỗ 


\section{Kỹ thuật tiến hành}

- Bệnh nhân được chuẩn bị như một cuộc phẫu thuật: sát trùng toàn bộ chiều dài chân bằng betadine, trải khăn vô trùng

- Bác sĩ rửa tay, mặc áo và mang găng vô trùng

- Đâm kim vào tĩnh mạch hiển dưới siêu âm định vị hoặc bộc lộ tĩnh mạch hiển bằng phương pháp Müller.

- Dùng phương pháp Seldinger để luồn dây điện cực đến đúng vị trí đã đánh dấu (cách quai 1 - $2 \mathrm{~cm}$ ). Sợi dây điện cực cố định bằng 1 khóa. Kiểm tra dây điện cực trong lòng tĩnh mạch ở đúng vị trí bằng siêu âm.

- Tiêm dung dịch đệm (natriclorua 0,9\%) xung quanh thân tĩnh mạch hiển dưới siêu âm từ xa về gần. Việc tiêm dung dịch đệm xung quanh tĩnh mạch có ba tác dụng. Tác dụng thứ nhất là giảm đau. Tác dụng thứ hai là ép tĩnh mạch nhỏ lại làm tăng hiệu quả tác dụng. Tác dụng thứ ba là tạo một môi trường nước bảo vệ xung quanh tĩnh mạch, làm giảm các biến chứng do tác dụng của hiệu ứng nhiệt lên các mô lân cận.

- Tùy theo thế hệ máy đốt nhiệt bằng sóng cao tần, năng lượng được sử dụng từ $25-30 \mathrm{~W}$, nhiệt độ phát ra từ $85^{\circ}-120^{\circ}$. Mỗi đoạn tĩnh mạch được can thiệp từ $5-7 \mathrm{~cm}$. Thời gian can thiệp trên mỗi đoạn tĩnh mạch là 20s.

- Sau thủ thuật, bệnh nhân được quấn băng thun ép hoặc mang vớ tĩnh mạch trong vòng 7 ngày và có thể xuất viện sau thủ thuật 2 giờ.

Bệnh nhân được tái khám sau 1 tuần. Những quai tĩnh mạch giãn còn sót lại được rút bỏ bằng phương pháp Müller hoặc được chích xơ dưới siêu âm.

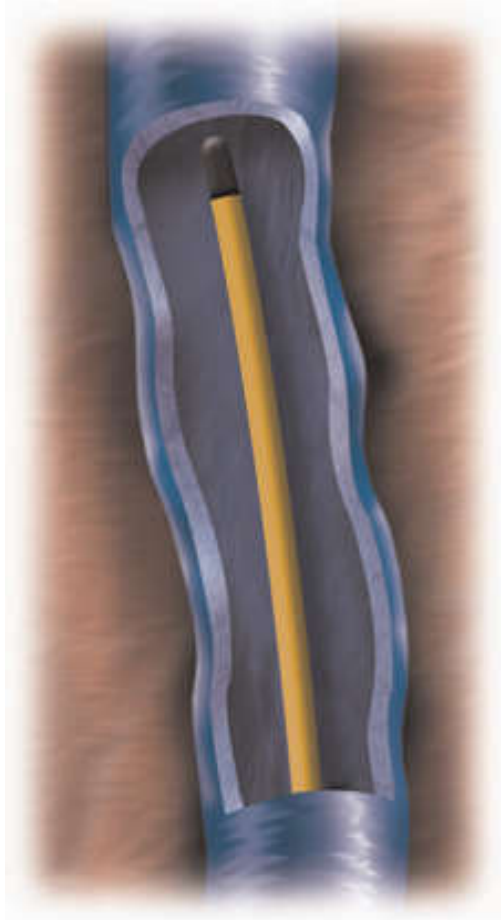

Disposable catheter inserted into vein

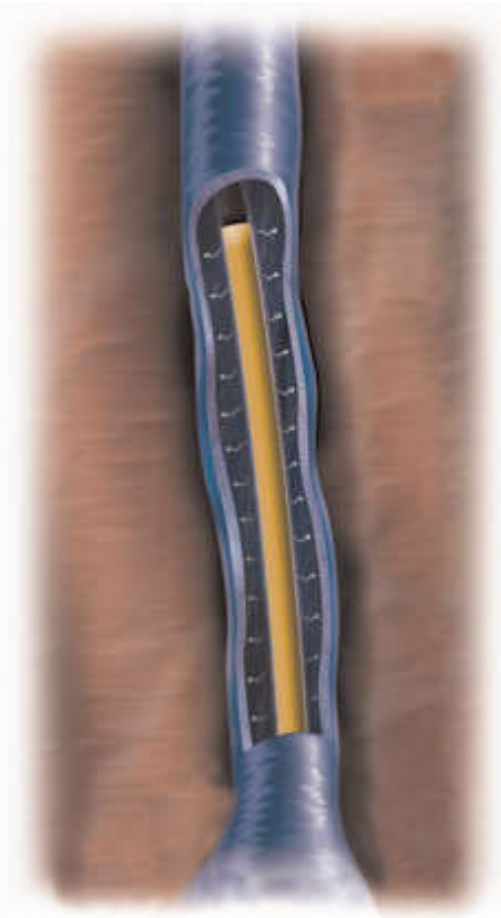

Vein heats and collapses

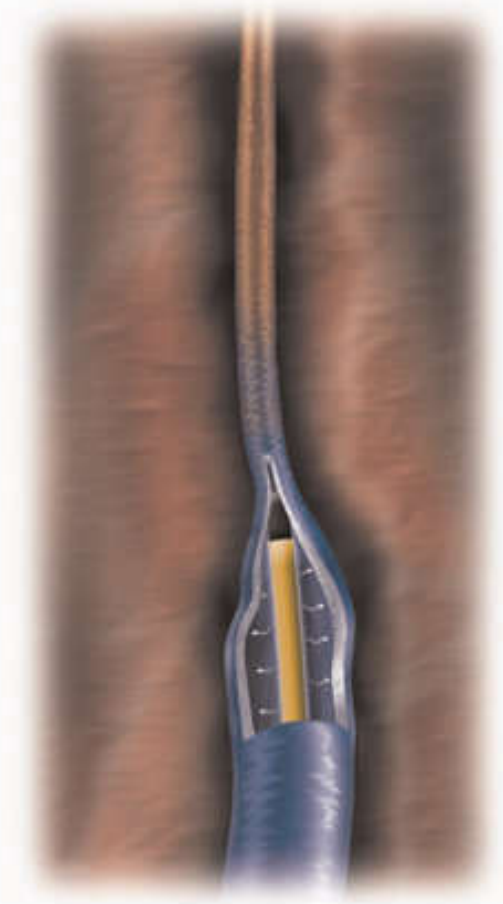

Catheter withdrawn, closing vein

Hình 7: Can thiệp xơ hóa tĩnh mạch bằng sóng cao tần 


\section{Đánh giá kết quả điều trị}

Đánh giá kết quả lâm sàng dụa trên tiêu chuẩn Mayo - Clinic [0, 8, 0]

- Rất tốt: không còn triệu chứng lâm sàng, không có các nhánh bên tái xuất hiện

- Tốt: không còn triệu chứng lâm sàng, ngoại trừ vài nhánh tĩnh mạch bên xuất hiện

- Khá: triệu chứng lâm sàng được cải thiện một phần và có các nhánh tĩnh mạch bên xuất hiện nhưng không có các nhánh chính tồn tại

- Thất bại: nhánh chính còn tồn tại hay tái lập

Đánh giá kết quả cận lâm sàng [0, 8, 0]

- Hình ảnh tắc đoạn tĩnh mạch hiển được làm laser trên siêu âm doppler

- Dòng trào ngược đoạn tĩnh mạch hiển được làm laser trên siêu âm doppler

Tai biến và biến chứng:

- Phỏng da

- Huyết khối tĩnh mạch sâu có thể gây thuyên tắc phổi [22]

- Tụ máu dưới da chỗ đâm kim

- Nhiễm trùng

Tiên lượng:

- Tỷ lệ thành công cao, 96 - 97\%.

- Thời gian nằm viện ngắn: bệnh nhân xuất viện trong ngày.

- Thời gian phục hồi nhanh: bệnh nhân trở lại với công việc sau khoảng 2 ngày.

\section{KẾT LUẬN}

Giãn tĩnh mạch nông chi dưới là bệnh lý ngày càng phổ biến ở nước ta. Hiện tại, có nhiều phương pháp để điều trị bệnh lý này. Xơ hóa tĩnh mạch bằng sóng cao tần là phương pháp điều trị ít xâm lấn, tỉ lệ thành công cao, ít biến chứng, tính thẩm mỹ cao, hồi phục nhanh. Cùng với can thiệp laser nội tĩnh mạch, phương pháp đốt nhiệt bằng sóng cao tần là những lựa chọn ban đầu của bác sĩ chuyên khoa mạch máu trong điều trị giãn tĩnh mạch nông chi dưới.

\section{TÀI LIỆU THAM KHẢO}

1. Claudio Allegra (2001), "Bệnh giãn tĩnh mạch", Khám phá bệnh suy tĩnh mạch mạn tính, Hội thảo bệnh lý tĩnh mạch - Trung Tâm Đào Tạo và Bồi Dưỡng Cán Bộ Y Tế Thành Phố Hồ Chí Minh, Servier, TP HCM, tr 15-24.

2. Claudio Allegra (2001), "Dịch tễ học bệnh tĩnh mạch", Khám phá bệnh suy tĩnh mạch mạn tính, Hội thảo bệnh lý tĩnh mạch - Trung Tâm Đào Tạo và Bồi Dưỡng Cán Bộ Y Tế Thành Phố Hồ Chí Minh, Servier, TP HCM, tr 3-6.

3. Phan Thanh Hải, Hồ Khánh Đức, Nguyễn Văn Việt Thành (2010), "Điều trị suy tĩnh mạch nông chi dưới bằng phương pháp laser nội tĩnh mạch với laser diode bước sóng 810 nm", Tạp chi Y họ TP HCM, tập 14 (1), tr 168-173.

4. Lê Thị Ngọc Hằng (2008), Đánh giá kết quả điều trị ngoại khoa giãn tĩnh mạch nông chi duới mạn tính, Luận văn tốt nghiệp bác sĩ nội trú, Đại học Y Dược TP HCM, TP HCM, tr 96-97.

5. Lê Nữ Thị Hoà Hiệp (2003), "Suy tĩnh mạch nông chi dưới mạn tính: yếu tố nguy cơ chỉ định ngoại khoa", Tạp chí Y hoc TP HCM, tập 7, tr 97-99.

6. Lê Nữ Thị Hoà Hiệp (2008), "Suy tĩnh mạch nông chi dưới mạn tính", Điều trị ngoại khoa lồng ngục - tim mạch, Nhà xuất bản Y học, TP HCM, tr 72-85.

7. Nguyễn Hoài Nam (2006), "Một số phương thức điều trị mới trong bệnh suy tĩnh mạch mạn tính", Cập nhật điều trị lồng ngưc - mạch máu, Nhà xuất bản Y học, TP HCM, tr 195-207.

8. Bùi Đức Phú, Bùi Minh Thành (2004), "Nghiên cứu dụng phẫu thuật Stripping trong 
điều trị ngoại khoa suy giãn tĩnh mạch nông chi dưới", Thông tin y dược học Việt Nam.

9. Văn Tần (2004), "Suy tĩnh mạch và giãn tĩnh mạch", Bài giảng bệnh học ngoại khoa, Nhà xuất bản Y Học, TP HCM, tr 416-439.

10. Văn Tần (2007), "Suy tĩnh mạch và giãn tĩnh mạch: bệnh lý và điều trị", Bài giảng diều trị học ngoại khoa, Nhà xuất bản Y Học, TP HCM, tr 440-451.

11. Nguyễn Văn Việt Thành (2011), "Đánh giá hiệu quả điều trị giãn tĩnh mạch hiển bằng phương pháp sử dụng laser nội mạch", Luận văn thạc sỹ y học, Đại học Y Dược TP. HCM, TP. HCM, tr 90.

12. Bull Phillip (2006), "History of Varicose Vein Surgery", The harley treet vein clinic, London, http://www.dr-bull.com/.

13. D.lafrati Mark, Thomas F. O'Donnell Jr. (2004), "Varicose veins", Haimovici's Vascular Surgery, Blackwell, pp 1058-1073.

14. Gohel, M.S., A.H. Davies (2009), "Radiofrequency ablation for uncomplicated varicose veins", Phlebology, 24 Suppl 1: p. 42-9.

15. Keagy Blair A., Mendes Robert R. (2007), "Superficial Venous Pathology and Therapies", Mastery of Surgery, Lippincott Williams \& Wilkins, Vol 2, pp 2503 - 2531.

16. Mosquera Damien (2010), "Historical overview of varicose vein surgery", Annals of Vascular Surgery, Vol 24 (8), pp 1159.

17. Parsi, K. (2009), "Catheter-directed sclerotherapy", Phlebology, 24(3): p. 98-107.

18. Reich-Schupke, S., A. Mumme, and M. Stucker (2011), "Histopathological findings in varicose veins following bipolar radiofrequencyinduced thermotherapy--results of an ex vivo experiment”. Phlebology, 26(2): p. 69-74.

19. Roos, M.T., B.L. Borger van der Burg, and J.J. Wever (2011), "Pain perception during and after VNUS ClosureFAST procedure", Phlebology, 26(5): p. 209-12

20. Sufian, S., S. Lakhanpal, and J. Marquez (2011), Superficial vein ablation for the treatment of primary chronic venous ulcers, Phlebology, 26(7): p. 301-6.

21. Tellings, S.S., R.P. Ceulen, and A. Sommer (2011), Surgery and endovenous techniques for the treatment of small saphenous varicose veins: a review of the literature, Phlebology, 26(5): p. 179-84.

22. Vedantham, S. (2008), Superficial venous interventions: assessing the risk of DVT, Phlebology, 23(2): p. 53-7.

23. Cao Văn Thịnh (2003), "Prévalence et facteurs favorisants de la maladie veineuse chronique chez les sujets de plus de la 50 ans à Ho Chi Minh ville", Revue international de documentation scientifique, Vol 55 (2), pp 49-53. 